науково-практична конференція : [зб. наук. пр.] (11 - 15 лютого 2007 року). - Полтава : Громадська асоціація «Аграрна наука та практика», 2007. - С. 216-220. 13. Султанова Н. В. Педагогічна мораль як чинник формування етичних переконань і потреб соціального педагога / Н. В. Султанова // Таврійський вісник освіти: науково-методичний журнал. - 2011. - №4 (36). - С. 24-30. 14. Сухомлинський В. О. Лист про педагогічну етику / В. О. Сухомлинський // Вибрані твори в 5ти томах / В. О. Сухомлинський. - К. : Рад. шк., 1977. - С. 591-600. 15. Хоружа Л. Етична компетентність учителя як основа реалізації гуманістичної парадигми освіти / Л. Хоружа // Шлях освіти. - 2003. - № 3. - С. 27-33. 16. Шевченко Л. Практическая педагогическая этика: экспериментально-дидактический комплекс / Л. Шевченко. - М. : Собор, 1997. - 506 с.

УДК 378.041

Є. Д. Харькова, викладач,

Сумський державний педагогічний університет імені А. С. Макаренка

\title{
ТЕНДЕНЦІЇ І ПЕРСПЕКТИВИ ТРАНСФОРМАЦІЇ ПЕРЕДШКІЛЬНОЇ ОСВІТИ В СУЧАСНОМУ ОСВІТНЬОМУ ПРОСТОРІ УКРАЇНИ
}

Харькова Є.Д. Тенденції і перспективи трансформації передшкільної освіти в сучасному освітньому просторі України

У статті розглянуто проблему трансформації передшкільної освіти в сучасному освітньому просторі України, визначено провідні чинники передшкільної освіти, які зумовили виокремлення передшкільної освіти.

Ключові слова: передшкільна освіта, трансформація передшкільної освіти, сучасний освітній простір, зміст передшкільної освіти.

Харькова Е. Д. Тенденции и перспективы трансформации предшкольного образования в современном образовательном пространстве Украины.

В статье рассматривается проблема трансформации предшкольного образования в современном образовательном пространстве Украины, названы основные факторы, обусловившие выделение предшкольного образования.

Ключевые слова: предшкольное образование, трансформация предшкольного образования, современное образовательное пространство, содержание предшкольного образования.

Kharkova E. D. Trends and prospects of transforming pre-school education in the modern educational environment in Ukraine.

The paper considers the problem of transformation of pre-school education in the modern educational environment of Ukraine, called factors leading pre-school education, have provided separation of preschool education.

Зміст державного стандарту України, перетворення іiї на самостійну державу, перехід до громадянського суспільства зумовили докорінне реформування й модернізацію системи освіти, зміни основних парадигм в освіті на всіх пї ланках, що у свою чергу, вимагає внесення відповідних змін до змісту освіти. У цьому зв'язку особливої уваги набуває дошкільна освіта як вихідна, початкової ланки загальної освіти. Провідними принципами української системи дошкільної освіти задекларовано в низці загальнодержавних нормативних документах, а саме: в Державній національній програмі «Освіта» (Україна XXI століття), Законі «Про дошкільну освіту», «Про охорону дитинства», Базовому компонентів дошкільної освіти, Державній цільовій програмі розвитку дошкільної освіти на період до 2017 року. В означених документах законодавчо закріплено прогресивні зміни, що відбулися в освітній політиці держави в період становлення незалежної України, а також прописано нові пріоритетні завдання подальшого розвитку системи дошкільної освіти. 
Існує нагальна потреба в узагальненні й систематизації досвіду розв’язання проблеми, що виникла на шляху розвитку вітчизняної дошкільної освіти, теоретичного осмислення їі здобутків, традицій, тенденцій, закономірностей, що допоможе усвідомити логіку становлення системи змісту перед шкільної освіти, а відтак, дозволить ураховувати багатогранність, динамічність об'єкта педагогічних досліджень, глибоко проникнути в його сутність, визначити етапи розвитку дошкільної освіти, зокрема мету, зміст і форми організації передшкільної освіти.

Особливий інтерес до розв'язання означеної проблеми становлять попередні періоди розвитку змісту освіти в дошкільній педагогіці, здобутки і втрати на шляху підготовки дітей до навчання у школі, які вимагають подальшого детального дослідження тенденцій, передумов і рушійних сил розвитку. Одержані результати допоможуть окреслити перспективи подальшого поступу в теорії і практиці передшкільної освіти.

Палітра доробків вітчизняних науковців, які присвятили свої праці проблемі підготовки дітей до школи, є досить різноплановою. Означений вектор освіти вивчали такі психологи Л. Венгер, Л. Виготський, П. Гончарук, В. Котирло, О. Любчик, Т. Маркова та інші психологічна готовність дітей до школи й оволодіння навчальною діяльністю; Т. Бабаєва, А. Богуш, 3. Борисова, Є. Водовозова, В. Логінова, 3. Михайлова, М. Морозова, Є. Тиихеєва, О. Усова, Є. Фльоріна та інші - розумовий розвиток дітей старшого дошкільного віку та готовність дитини до школи; Н. Баглаєва, Л. Білоусько, А. Конфорович, О. Кудрявцева, 3. Лебедєва та інші - математична підготовка дітей до школи; формування мовленнєвих умінь і навичок у процесі навчально-мовленнєвої діяльності дітей та мовленнєвої підготовки їх до навчання у школи такі лінгводидакти, як: А. Арушанова, А. Богуш, Н. Гавриш, Л. Калмикова, Т. Котик, К. Крутій, Н. Савінова, та інші.

Mema cmammi - проаналізувати особливості українського освітнього простору передшкільної освіти України.

XXI століття ознаменувало перехід до суспільства нового типу. Цивілізаційні тенденції розвитку сучасного суспільства висувають нові вимоги як до конкретної людини, так і до всього людства. Цивілізаційні зміни не можуть не позначитися на характері і змісті освіти, оскільки освіта, віддзеркалюючи соціально-економічні запити, стає вагомим ресурсом у конкуруючих ринкових суспільствах, які пришвидшують інноваційний поступ. У цьому зв'язку змінюється і ставлення суспільства до підготовки майбутнього покоління до життя в нових цивілізаційних умовах.

Зазначимо, що до найважливіших світових, цивілізаційних тенденцій, які зазначають зовнішні впливи на трансформації змісту освіти, належать повсюдна глобалізація й інформатизація життя, якій не може протистояти жодне суспільство. Глобалізація, за словами В. Кременя, поступово перетворює світ на єдиний простір, де без перешкод рухаються товари, послуги, капітал, інформація і особливо люди, збагачуючи один одного, прискорюючи змінність суспільного життя.

Українська держава шукає оптимальні шляхи входження до загальноцивілізованого, у тому числі й освітнього, руху зі збереженням і примноженням кращих національних здобутків: пріоритет загальнодержавної суспільної підтримки освіти, навчання, виховання, розвиток гармонійної, гуманної й соціально відповідальної особистості [1, c. 12]. Розвиток змісту української освіти на початку XX століття відбувався ще в умовах суперечливих внутрішніх впливів політичних, економічних, культурних і освітянських чинників. Отже, в умовах глобалізації, зростання ролі знань та інформативності суспільства освіта позиціонується у світовому цивілізаційному світі як єдиний інструмент формування людини нового покоління, здатної жити й працювати в епоху динамічних змін. Це зумовлює необхідність оновлення всіх ланок освіти, в тому числі їі дошкільної й передшкільної, а їі зміст розглядати як системоутворювальну базу, що буде вирішальним чинником реалізації нової державної політики, нових цивілізованих запитів та устремлінь. 
Щодо дошкільної ланки освіти, з'ясувано такі проблеми, які виникли на початку XXI століття. Низька народжуваність дітей в Україні та економічна нестабільність призвела до скорочення кількості дитячих садків майже вдвічі. Але починаючи з 2002 року у зв'язку 3 економічним зростанням країни, зайнятістю жінок на виробництві збільшився попит на дошкільну освіту, збільшився й контингент дітей, які почали відвідувати дошкільні заклади. У країні виникла нова проблема - нестача місць у ДНЗ, неможливість задовольнити всіх бажаючих батьків віддавати дітей до ДНЗ, оскільки в попередньому столітті ці дитячі садки було закрито. Відсутність місць у державних дошкільних закладах стимулювала появу нових недержавних приватних дошкільних установ. Здебільш приватні дитячі заклади працювали за розробленими «авторськими» програмами, ніким не рецензованими й незатвердженими МОН. У таких закладах і нині здійснюється тільки навчальна діяльність, ігнорується виховання й розвиток індивідуальності особистості дошкільника. Зауважимо, саме на початку XXI століття активізувалася гувернантська практика сімейного виховання, за якою гувернер навчав і готував на прохання батьків дітей до школи, тобто вчив дітей писати, читати, рахувати, вивчати вірші тощо. Натомість такі домашні діти були позбавлені ігрової провідної діяльності й найголовнішого - спілкування 3 однолітками, вміння жити й навчатися в колективі. Переповненість вікових груп дітей призвела до зниження якості підготовки дітей до навчання у школі. Окрім того, ДНЗ не мали можливості охопити всіх дітей у державі, тому частина дітей (близько 40\%) підготовку до школи отримувала в підготовчих групах школи чи підготовку в сім'ї, що було передбачено Базовим компонентом дошкільної освіти. Подолання одноманітності, поширення мережі приватних дошкільних закладів, спеціалізованих ДНЗ, груп 3 поглибленим вивченням іноземної мови, з поглибленою роботою з дітьми з естетичного виховання та інших виховних напрямів, різноманітність програм навчання і виховання дітей стали однією з причин нерівності знань дітей на момент вступу їх до школи. Цей факти ми розглядаємо як позитивний, так і негативний. 3 одного боку, в окремих ДНЗ орієнтувалися не на «середню дитину», а враховували ії можливості й інтереси, створювали сприятливі умови для дітей з достатнім і високим рівнем розумового розвитку, для обдарованих дітей. 3 іншого, - для вступу до школи, коли діти, не охоплені ДНЗ, мали неоднакові стартові можливості для подальшої освіти. Отже, тенденція наростання нерівності в освіті пов'язана з глобальними соціальними процесами і має об'єктивний характер [2].

Особливістю розвитку змісту передшкільної освіти 2000-і роки стало відродження традицій початку і середини XX століття: навчання рідною мовою, використання в навчанні та вихованні народної педагогіки. Максимальна доступність отримання передшкільної освіти, відкриття більшої кількості ДНЗ із групами дітей передшкільного віку, створення прогулянкових груп для підготовки дітей до школи, паралельне існування державних і недержавних дошкільних навчальних закладів освіти з єдиною програмою підготовки дітей до школи. Про турботу держави щодо дітей перед шкільного віку свідчить Лист МОН України №1/9 - 431 від 17 серпня 2005 року «Про організацію короткотривалого перебування дітей в дошкільних закладах» [3].

Важливість перед шкільної освіти в Україні зазначено в Законі України 2442-VI «Про внесення змін до законодавчих актів з питань загальної середньої та дошкільної освіти щодо організації навчально-виховного процесу» 6 липня 2010 року, доповнивши Закон України «Про дошкільну освіту» введенням положення про обов'язкову дошкільну освіту дітей старшого дошкільного віку. У зв'язку з цим у Листі Міністерства освіти і науки України від 18.08.2010 р. №1/9-570 «Про організацію роботи 3 дітьми дошкільного віку у 2010-2011 навчальному році» [5] було дано роз'яснення щодо створення умов для здобуття дітьми дошкільної освіти в містах та сільській місцевості. Зазначимо, що введення навчання дітей у школі з 6 років призвело до закриття підготовчих груп у ДНЗ, у зв'язку з чим виникла проблема з тими дітьми, які за станом здоров'я не змогли розпочати систематичне навчання у школі. Особливо потерпали від цього діти, які з різних причин не відвідували до цього дошкільних закладів, а виховувались в сім’і. 
Для розв'язання напрямів подальшого розвитку змісту передшкільної освіти в Україні необхідно виявити тенденції як ті, що були провідними у минулому столітті, так і ті, що виявляються в сучасному змісті дошкільної, передшкільної і початкової освіти, оскільки вони $є$ орієнтиром моделювання змісту системи передшкільної освіти в сучасному освітньому просторі, тобто тенденції, зумовлені вимогами часу і згодом можуть стати інноваційним напрямом розвитку загальної перед шкільної освіти.

Виклики XXI століття й ті цивілізаційні зміни, що нині відбуваються, вимагають окреслення нових завдань та визначення перспективних тенденцій модернізації і подальших трансформацій насамперед загального змісту освіти. Провідними тенденціями оновлення світового освітнього простору на сучасному етапі $є$ : орієнтація більшості країн на перехід від елітної освіти до високоякісної освіти для всіх; поглиблення міждержавного співробітництва у галузях освіти, яке залежить від потенціалу національної системи освіти і від рівня умов партнерства держави і окремих учасників; розширення гуманітарного складника у світовій освіті в цілому за рахунок уведення людиноорієнтованих наукових і навчальних дисциплін; значне поширення нововведень за умов збереження національних традицій, що склалися, та національної ідентичності країн і регіонів [5, с. 190].

Отже, відповідно до означених актуальних напрямів розбудови системи дошкільної освіти в Україні [1, с. 130], ми визначили провідні тенденції модернізації і подальших трансформацій змісту перед шкільної освіти як проміжної ланки між дошкільною і початковою освітою. Серед найбільш головних і перспективних тенденцій окреслимо такі: стандартизація змісту передшкільної освіти; орієнтація змісту перед шкільної освіти на реалізацію принципу дитиноцентризму; орієнтація на компетентнісну парадигму передшкільної освіти; всеохопленість дітей перед шкільного віку їх перебування у навчальних закладах різного типу; варіативність програм і методик передшкільної освіти.

\section{Література}

1. Біла книга національної освіти України / за ред. В. Г.Кременя. - К. : ТОВ «Інформаційні системи», 2010. - 342 с. 2. Курило В. С. Становлення і розвиток системи освіти та педагогічної думки східноукраїнського регіону в XX столітті: дис. доктора пед. наук: 13.00 .01 / Курило В. С. Луганськ, 2000. - 477 с. 3. Лист МОН України «Про організацію короткотривалого перебування дітей у дошкільних навчальних закладах» №1/9-431 від 17.08.2005 р. [Електронний ресурс]. Режим доступу: htt: // www.yur-info. org. da / doc / jsp /. 4. Авдюгіна К. Про підготовку дітей до навчання в школі / К. Авдюгіна // Дошкільне виховання. - К. : Рад. школа, 1959. - №12. - С. 10-13. 5. Педагогіка вищої школи : [навч. посіб.] / 3. Н. Курлянд, Р. І. Хмелюк, А. В. Семенова та ін.. Одеса : ПДПУ ім. К. Д.Ушинського, 2002. - 344 с.

УДК 378:37.011.33

Г. В. Хімрова, аспірант,

РВНЗ «Кримський гуманітарний університет» (м. Ялта)

\section{РЕАЛІЗАЦІЯ ТЕХНОЛОГІЇ ГРОМАДЯНСЬКОГО ВИХОВАННЯ СТУДЕНТІВ У НАВЧАЛЬНО-ВИХОВНОМУ ПРОЦЕСІ ВНЗ}

Хітрова Г. В. Реалізація технології громадянського виховання студентів у навчально-виховному процесі ВНЗ.

У статті розкрито сутність і зміст технології громадянського виховання студентської молоді в навчально-виховному процесі вищого навчального закладу. Визначено ключові етапи та напрями діяльності суб’єктів вищої школи. Наведено приклади використання форм і методів формування громадянськості студентів.

Ключові слова: технологія, технологія громадянського виховання, навчально-виховний процес.

Хитрова А. В. Реализация технологии гражданского воспитания студентов в учебновоспитательном процессе вуза.

В статье раскрыто сущность и содержание технологии гражданского воспитания студенческой молодежи в учебно-воспитательном процессе высшего учебного заведения. Определены ключевые 